\title{
Efektifitas Pembelajaran Kolaboratif Berbasis Online Terintegrasi E- Akademik Terhadap Kemampuan Berpikir Kritis dan Sikap Terhadap Matematika
}

\author{
Wawan $^{1} \&$ Agus Setiawan ${ }^{2}$
}

\begin{abstract}
1,2 Institut Agama Islam Ma'arif NU Metro, Indonesia

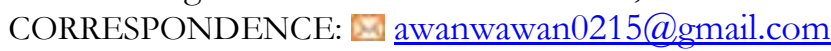

\section{Article Info}

Article History

Received : 15-07-2021

Revised : 26-07-2021

Accepted : 25-08-2021

\section{Keywords:}

Kolaboratif,

Online,

Berpikir Kritis,

Sikap Matematika

\begin{abstract}
Abstrak
Tujuan penelitian ini adalah untuk mengetahui mana yang lebih efektif antara model pembelajaran kolaboratif berbasis online dengan pembelajaran langsung berbasis online terhadap pencapaian kemampuan berpikir kritis dan sikap mahasiswa terhadap matematika.

Pendekatan penelitian yang digunakan adalah penelitian kuantitatif dengan metode eksperimental semu. Penelitian dilakukan di Institut Agama Islam Ma'arif NU Metro, Indonesia, pada tahun akademik 2020/2021. Sampel penelitian adalah mahasiswa pendidikan matematika semester IV (empat) yang sedang menempuh mata kuliah geometri. Kelas eksperimen terdiri dari 31 mahasiswa sementara kelas kontrolnya berjumlah 30 mahasiswa. Sampel penelitian diambil dengan teknik cluster random sampling. Instrumen pengumpulan data yang digunakan adalah tes dan angket. Tes digunakan untuk melihat kemampuan berpikir kritis, sementara angket dalam bentuk skala Likert digunakan untuk mengukur sikap mahasiswa terhadap matematika. Adapun teknik analisis data yang digunakan adalah statistik uji analisis variansi multivariat satu jalur.

Penelitian ini memberikan hasil bahwa model pembelajaran kolaboratif berbasis online lebih baik daripada pembelajaran langsung berbasis online terhadap pencapaian peserta didik dalam kemampuan berpikir kritis dan sikap terhadap matematika, baik secara multivariat maupun univariat.
\end{abstract}

\section{Introduction}

Masa pandemi covid 19 yang melanda hampir seluruh dunia termasuk Indonesia mengakibatkan munculnya banyak krisis di berbagai bidang kehidupan, tak terkecuali bidang pendidikan. Dengan semakin tingginya jumlah kasus covid di Indonesia mengakibatkan sistem pembelajaran tatap muka tidak dapat dilaksanakan sebagaimana biasanya. Sejak meluasnya virus covid-19 di berbagai daerah, sistem pembelajaran lebih banyak dilakukan secara daring meskipun beberapa sekolah atau perguruan tinggi tetap ada yang menerapkan blended learning dalam skala terbatas. Memperhatikan kondisi ini, maka inovasi pembelajaran menjadi penting untuk dilakukan. Sistem pembelajaran daring yang banyak menjadi pilihan para pendidik perlu didesain sedemikian rupa sehingga dapat mengoptimalkan proses dan hasil pembelajaran. Optimalisasi proses pembelajaran daring menjadi penting untuk diperhatikan oleh para pendidik karena masih ditemukannya banyaknya masalah terkait prestasi belajar peserta didik di Indonesia, termasuk didalamnya adalah prestasi belajar belajar matematika. 


\section{Efektifitas Pembelajaran Kolaboratif Berbasis Online}

Melihat hasil belajar matematika di Indonesia, diketahui bahwa kemampuan matematika peserta didik cenderung rendah. Dari Laporan Trends International Mathematics and Science Study (TIMSS) tahun 2015 (Mullis et al., 2016) dapat diketahui bahwa hanya sekitar 5\% peserta didik di Indonesia yang mampu menyelesaikan soal-soal matematika bertipe high dan advance, dimana kedua tipe soal tersebut membutuhkan ketrampilan peserta didik dalam berpikir kritis dan kreatif. Hasil PISA tahun 2015 (OECD, 2016) dan 2018 (OECD, 2018) juga menunjukkan bahwa kemampuan peserta didik di Indonesia dalam bermatematika masih sangat rendah, bahkan masih di bawah standar.

Berdasarkan hasil TIMSS tahun 2015 (OECD, 2016) juga diketahui bahwa secara kuantitatif tingkat kesukaan peserta didik terhadap pembelajaran matematika masuk kategori tinggi dimana $66 \%$ peserta didik menunjukkan sikap sangat suka terhadap matematika, sementara yang tidak suka terhadap pembelajaran matematika hanya sebesar 4\%. Meskipun demikian, rupanya hasil tersebut tidak linier dengan keyakinan peserta didik terhadap matematika. Berdasarkan hasil TIMSS 2015 tersebut diketahui bahwa hanya 23\% peserta didik yang mempunyai keyakinan terhadap matematika kategori sangat yakin, sementara untuk kategori tidak yakin sebesar $24 \%$.

Memperhatikan berbagai masalah tersebut, muncul tantangan baru bagi pendidik kontemporer untuk mengubah cara dalam mempersiapkan peserta didik di masa depan. Dengan kata lain, seorang pendidik melalui sebuah lembaga pendidikan harus berbenah diri dalam pemberdayaan peserta didik untuk memperoleh kompetensi atau ketrampilan-ketrampilan yang dibutuhkan di Abad-21 sesuai dengan kondisi, tuntutan dan kebutuhan zaman. Belum optimalnya kompetensi peserta didik dalam pembelajaran juga sangat dimungkinkan karena model pembelajaran yang diimplementasikan pendidik di kelas memang kurang tepat. Hal ini seperti disampaikan Syah (2010) yang menyatakan bahwa salah satu faktor yang mempengaruhi belajar peserta didik adalah faktor eksternal dan faktor pendekatan belajar. Faktor eksternal merupakan faktor lingkungan yakni kondisi lingkungan di sekitar peserta didik dan faktor pendekatan belajar mencakup metode dan strategi yang digunakan dalam kegiatan pembelajaran. Seorang pendidik matematika seharusnya menerapkan budaya kelas baru dengan menjadikan peserta didik terlibat secara aktif dalam pembelajaran sosial dan kolaboratif dalam mewujudkan hasil belajar yang optimal, meskipun masih dalam masa pandemi covid-19.

Mencermati perkembangan pendidikan matematika secara global seperti yang diinformasikan oleh Marsigit et al. (2015) diketahui bahwa sistem pendidikan pembelajaran telah bergeser dari pembelajaran yang berpusat pada pendidik menjadi pendidikan/pembelajaran yang berpusat pada peserta didik. Transfer of knowledge dari guru ke murid telah dianggap sebagai paradigma yang tidak sesuai dengan hakikat mendidik pada masa kini. Terkait hal ini, Marsigit et al. (2015) menyatakan bahwa paradigma baru yakni 'developing', dimana guru berperan sebagai fasilitator, dapat digunakan sebagai upaya mengembangkan potensi peserta didik. Dari beberapa informasi ini, seharusnya guru berani untuk mengimplementasikan model-model pembelajaran yang dapat mengaktifkan peserta didik. Dalam merumuskan program perbaikan, seyogyanya seorang guru dapat mengelola lingkungan belajar dengan lebih baik, dengan memberikan kesempatan bagi peserta didik untuk terlibat aktif dalam pembelajaran matematika. Hal ini sejalan dengan pemikiran Ayele (2016) yang menyatakan bahwa guru harus mendorong dan menghargai gagasan kreatif peserta didik; 
memotivasi peserta didik yang terlibat dengan matematika; menerapkan pengetahuan latar belakang yang kuat secara reguler dalam matematika; mendorong perbedaan pendapat dan keragaman; serta memberikan umpan balik positif secara teratur.

Atas dasar hal tersebut, penulis tertarik untuk menerapkan model pembelajaran kolaboratif berbasis online terintegrasi E-Akademik untuk meningkatkan kemampuan berpikir kritis dan sikap mahasiswa terhadap matematika. Beberapa penelitian juga telah menunjukkan bahwa implementasi pembelajaran kolaboratif dalam pembelajaran matematika telah memberikan hasil belajar yang memuaskan, misalnya penelitian Retnowati et al. (2016), Ulia (2018), Wawan et al. (2018), Setiawan et al. (2020) dan Karimah et al., (2019). Beberapa penelitian tersebut memberikan refrensi penting bagaimana model pembelajaran kolaboratif berkontribusi secara nyata dalam pencapaian prestasi belajar peserta didik.

\section{Method}

Pendekatan penelitian ini adalah penelitian kuantitatif dengan menggunakan desain eksperimental semu. Penelitian ini dilakukan di Institut Agama Islam Ma'arif NU Metro, Indonesia, pada tahun akademik 2020/2021. Sampel penelitian adalah mahasiswa pendidikan matematika semester IV (empat) yang sedang menempuh mata kuliah geometri. Kelas eksperimen pada penelitian ini terdiri dari 31 mahasiswa, sementara untuk kelas kontrolnya berjumlah 30 mahasiswa. Sampel diambil menggunakan teknik cluster random sampling. Instrumen pengumpulan data yang digunakan adalah tes dan angket. Tes digunakan untuk melihat kemampuan berpikir kritis, sementara angket digunakan untuk mengukur sikap mahasiswa terhadap matematika. Efektifitas model pembelajaran ini dilihat dari uji akhir terhadap dua variabel yang diteliti setelah eksperimen selesai dilaksanakan.

Teknik analisis data yang digunakan adalah statisti parametris dengan menggunakan statistic uji analisis variansi multivariat satu jalur. Sebelum dianalisis lebih lanjut dengan statistic uji yang dimaksud, telah dilakukan uji persyaratan analsis yang meliputi: 1) uji normalitas multivariat, 2) uji homogenitas variansi dan 3) uji homogenitas matriks variansi dan kovariansi (Wawan, 2020). Adapun untuk membantu analisis data digunakan software statistik SPSS tipe 21.

\section{Result and Discussion}

Sebelum dianalisis lebih lanjut dengan statistik uji analisis variansi multivariat, telah dilakukan uji persyaratan analisis dengan hasil sebagai berikut.

\section{Uji Normalitas Multivariat}

Uji normalitas multivariat dilakukan dengan membuat scater plot dan uji korelasi antara nilai mabalanobis distance dengan Chi Kuadrat. Scater plot dari uji ini ditampilkan pada gambar di bawah ini. 


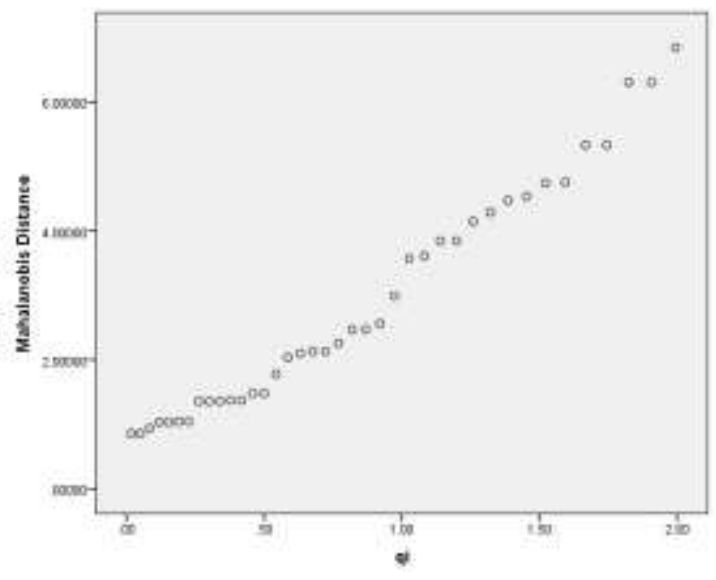

Gambar 1. Scatter Plot Hasil Uji Normalitas Multivariat

Berdasarkan Scatter Plot tersebut dapat dilihat bahwa sebaran datanya cenderung linier atau membentuk garis lurus. Adapun dari uji korelasi antara nilai mabalanobis distance dengan Chi Kuadrat diperoleh koefisien korelasi sebesar 0,987 dan signifikansi amatan sebesar 0,000. Berdasarkan dua kriteria yang digunakan untuk pengujian normalitas multivariat, maka dapat disimpulkan bahwa sampel pada penelitian ini berasal dari populasi berdistribusi normal multivariat.

\section{Uji Homogenitas Variansi Populasi}

Hasil uji homogenitas variansi dengan statistik uji Levene disampaikan dalam tabel berikut.

\section{Tabel 1. Hasil Uji Homogenitas Multivariat}

\begin{tabular}{|l|c|c|c|c|}
\hline & F & Df1 & Df2 & Sig. \\
\hline Kritis & .001 & 1 & 59 & .982 \\
\hline Sikap & .679 & 1 & 59 & .413 \\
\hline
\end{tabular}

Berdasarkan tabel tersebut diperoleh nilai signifikansi amatan yang lebih dari 0,05 untuk masing-masing kelompok populasi sehingga dapat disimpulkan bahwa untuk kedua kelompok populasi, variansinya adalah sama atau homogen.

\section{Uji Homogenitas matriks kovariansi dan variansi.}

Berdasarkan hasil uji Box's M diperoleh nilai taraf signifikansi amatan sebesar 0.899. Karena lebih dari 0,05 maka dapat disimpulkan bahwa matrisk kovariansi dari variabel terikat pada semua kelompok populasi adalah sama.

Setelah uji persyaratan analisis terpenuhi, selanjutnya dilakukan uji analisis multivariate dengan $U_{j i}$ Hoteling Trace. Berdasarkan hasil uji ini diperoleh nilai $\mathrm{F}$ sebesar 7.542 dengan taraf signifikansi amatan sebesar 0.001. Karena nilai signifikansi amatan kurang dari 0,05 sehingga diputuskan bahwa $H_{0}$ diterima. Berdasarkan hasil ini dapat disimpulkan bahwa kedua model pembelajaran memberikan hasil yang berbeda terhadap kemampuan berpikir kritis dan sikap mahasiswa terhadap matematika. Karena ada perbedaan selanjutnya dilakukan uji univariat untuk melihat hasil penelitian secara lebih spesifik. Berikut hasil uji univariat yang telah dilakukan. 
Wawan \& Agus Setiawan

Tabel 2. Hasil Uji Univariat

\begin{tabular}{lllrrr}
\hline $\begin{array}{c}\text { Dependent } \\
\text { Variable }\end{array}$ & \multirow{2}{*}{ (I) Model } & (J) Model & $\begin{array}{r}\text { Mean Difference (I- } \\
\text { J) }\end{array}$ & Std. Error & \multirow{2}{*}{ Sig. } \\
\hline \multirow{2}{*}{ Kritis } & Kolaboratif & Langsung & $8.295^{*}$ & 2.856 & .005 \\
& Langsung & Kolaboratif & $-8.295^{*}$ & 2.856 & .005 \\
\hline \multirow{2}{*}{ Sikap } & Kolaboratif & Langsung & $8.055^{*}$ & 3.048 & .011 \\
& Langsung & Kolaboratif & $-8.055^{*}$ & 3.048 & .011 \\
\hline
\end{tabular}

Berdasarkan data tersebut diketahui bahwa untuk variabel kemampuan berpikir kritis, diperoleh nilai Sig. Sebesar 0,05. Karena kurang dari 0,05 maka dapat diputuskan bahwa $H_{0}$ ditolak sehingga dapat disimpulkan bahwa ada perbedaan pengaruh antara model pembelajaran kolaboratif berbasis online dengan model pembelajaran langsung berbasis online. Karena rerata marginal model kolaboratif berbasis online lebih tinggi daripada model pembelajaran langsung berbasis online maka dapat disimpulkan bahwa model pembelajaran kolaboratif berbasis online memberikan kemampuan berpikir kritis yang lebih baik daripada model pembelajaran langsung berbasis online.

Selanjutnya, berdasarkan hasil uji hipotesis untuk variabel sikap mahasiswa terhadap matematika, diperoleh nilai Sig. sebesar 0,011. Karena kurang dari 0,05 maka dapat disimpulkan bahwa ada perbedaan pengaruh antara model pembelajaran kolaboratif berbasis online dengan model pembelajaran langsung berbasis online. Karena rerata marginal model pemebalajaran kolaboratif berbasis online lebih tinggi daripada model pembelajaran langsung berbasis online maka dapat disimpulkan bahwa model pembelajaran kolaboratif berbasis online menghasilkan sikap terhadap matematika yang lebih baik daripada model pembelajaran langsung berbasis online.

Berdasarkan hasil pengujian hipotesis diperoleh bahwa model pembelajaran kolaboratif berbasis online menghasilkan kemampuan berpikir kritis dan sikap terhadap matematika yang lebih baik dari pemebalajaran langsung berbasis online baik secara multivariat maupun univariat. Hasil uji empiris telah sesuai dengan hipotesis yang dirumuskan sebelumnya. Hasil ini juga memberikan dukungan terhadap penelitian lain mengenai efektivitas model pembelajaran ini dalam pembelajaran matematika, seperti penelitian yang telah dilakukan oleh Retnowati et al. (2016), Ulia (2018), Wawan et al. (2018) dan Karimah et al. (2019).

Berdasarkan hasil penelitian ini, implementasi model pembelajaran kolaboratif dalam pembelajaran matematika layak dipertimbangkan oleh para pendidik baik pada sekolah menengah maupun perguruan tinggi. Kegiatan kerjasama secara berkelompok dalam pembelajaran kolaboratif menekankan pada kerjasama saling kesepahaman, saling menghargai, tanggung jawab, dan penuh tenggang rasa. Melalui implementasi model pembelajaran kolaboratif akan memberikan pemahaman yang lebih mendalam dan meningkatkan sikap peserta didik terhadap matematika sebagaimana telah ditunjukkan dalam penelitian ini.

Memberikan kesempatan kepada mahasiswa untuk mengekplorasi berbagai referensi belajar secara online yang dilakukan secara kolaboratif dapat mengoptimalkan kemampuan peserta didik dalam matematika, terutama kemampuan berpikir kritis. Peran seorang pendidik sebagai mediator menjadi salah satu kunci dalam pembelajaran apabila pengembangan kemampuan bermatematika peserta didik akan berjalan secara 
optimal. Melalui kerjasama antar peserta didik dimana mereka diberikan kebebasan dalam menentukan bahan yang akan dikaji, diberi kesempatan untuk saling memberi bantuan belajar serta saling mengevaluasi merupakan hal penting untuk dilakukan. Melalui pembelajaran kolaboratif berbasis online telah memberikan efek yang positif bagi pengembangan peserta didik, baik dalam ranah kognitif maupun afektif.

\section{Conclusion}

Berdasarkan hasil analisis data diperoleh kesimpulan bahwa model pembelajaran kolaboratif berbasis online menghasilkan kemampuan berpikir kritis dan sikap terhadap matematika yang lebih baik dari pembelajaran langsung berbasis online, baik secara multivariat maupun univariat. Hal ini menjadi referensi penting bagi pendidik matematika dalam merencanakan program-program perbaikan proses pembelajaran di era pandemi covid-19. Pembelajaran online harus didesain seoptimal mungkin untuk memperoleh hasil pembelajaran yang memuaskan. Pengembangan potensi peserta didik melalui model pembelajaran inovatif seperti ditunjukkan dalam penelitian ini perlu dipertimbangkan oleh pendidik matematika.

Penulis menyampaikan terimakasih kepada Institut Agama Islam Ma'arif NU Metro yang telah memberikan bantuan untuk penelitian ini melalui skema Program Penelitian Pengembangan Prodi.

\section{References}

Ayele, M. A. (2016). Mathematics teachers' perceptions on enhancing students' creativity in mathematics. Mathematics Education, 11(10), 3521-3537.

Karimah, I., Suhendri, H., \& Werdiningsih, C. E. (2019). Peranan Metode Pembelajaran Collaborative Learning Terhadap Pemecahan Masalah Matematika. Jurnal Kajian Pendidikan Matematika, 4(2), 155162.

Marsigit, Ilham, R., \& Murdiyani, M. . (2015). Filsafat Matematika. Yogyakarta: UNY Press.

Mullis, I. V. ., Martin, M. O., \& Foy, P. (2016). TIMSS 2015 International Results in Mathematics. http://timssandpirls.bc.edu/timss2015/international-results/timss-2015/mathematics/studentachievement/

OECD. (2016). Pisa 2015. Pisa 2015, 2015. https://doi.org/10.1596/28293

OECD. (2018). PIS A 2018: Insights and Interpretations.

Retnowati, E., Ayres, P., \& Sweller, J. (2016). Can Collaborative Learning Improve the Effectiveness of Worked Examples in Learning Mathematics? Journal of Educational Psychology, 109(5), 1-14. https://doi.org/10.1037/edu0000167

Setiawan, A , Degeng, İ , Sa'dijah, C , Praherdhiono, H . (2020). The Effect Of Collaborative Problem Solving Strategies And Cognitive Style On Students' Problem Solving Abilities . Journal for the Education of Gifted Young Scientists , 8 (4) , 1618-1630 . DOI: 10.17478/jegys.812781

Syah, M. (2010). Psikologi pendidikan. Bandung: Remaja Rosda Karya.

Ulia, N. (2018). Efektivitas Colaborative Learning Berbantuan Media Short Card Berbasis It Terhadap Pemahaman Konsep Matematika. Jurnal Ilmiah Pendidikan Dasar, 3(2), 1. https://doi.org/10.30659/pendas.3.2.1-11

Wawan. (2020). Teknik Analisis Data Penelitian Pendidikan dengan Bantuan Software Statistik. Yogyakarta: UNY Press.

Wawan, W., Marsigit, M., Fitria Ningsih, E., Widyawati, S., Kusumaningtyas, W., Mahmudi, M., Suhono, S., Mukhlishin, A., Ganda Putra, F., \& Setiawan, A. (2018). Technology-Integrated Collaborative Learning: Convenient Alternative in Developing the Problem Solving Capability and Positive Attitude towards Mathematics. International Journal of Engineering \& Technology, 7(3.2), 737. https://doi.org/10.14419/ijet.v7i3.2.18739 